\title{
Preparation of Recipient Wound Bed by Adipose Derived Stem Cell for Skin Flaps in Dogs
}

\author{
M. Gokulakrishnan ${ }^{1 *}$, L. Nagarajan ${ }^{1}$ and T. A. Kannan ${ }^{2}$ \\ ${ }^{1}$ Department of Clinics, Madras Veterinary College, Tamil Nadu Veterinary and Animal \\ Sciences University, India \\ ${ }^{2}$ Department of Veterinary Anatomy, ${ }^{3}$ Department of Veterinary Surgery and Radiology, \\ Madras Veterinary College, Tamil Nadu Veterinary and Animal Sciences University, India \\ *Corresponding author
}

Keywords

Adipose derived stem cell, Recipient wound bed, Skin flap, Dogs

Article Info

Accepted:

05 February 2020

Available Online:

10 March 2020

\section{A B S T R A C T}

Open wound management, until the wound is considered suitable for reconstruction or until it has healed by second intention, has been the treatment of choice for centuries. The aim of wound healing is to promote rapid wound closure and prevent excess scar formation. The canine adipose cells obtained not exceeding the second passage was used for topical administration with appropriate substrate on the recipient wound bed. The flaps performed in the present study were flank and elbow rotational flap, transposition flap, caudal superficial epigastric flap, single and bipedicle advancement flaps. The flaps were selected based on the location and site of the wound. Subjective evaluation of wound healing based on the physical observations, clinical photography, wound planimetry studies were evaluated. Additionally, hematological, bacteriological, biochemical, and histopathological evaluation were done for the recipient wound bed and skin flap. A subjective analysis of vascularity of the donor site was performed through Colour flow Doppler ultrasonography.

\section{Introduction}

The aim of wound healing is to promote rapid wound closure and prevent excess scar formation. To stimulate wound healing, a variety of methods have been used, such as the topical application of herbal remedies like Aloe vera extract, the use of soft laser, natural honey and electromagnetic pulses (Houghton and Campbell, 1999). Even though good results have been achieved by these methods, the customary approach remains the 
prevention of infection using antibacterial and antiseptic agents, and sometimes hygroscopic powders (Schultz et al., 2005).

Skin flaps or free grafts should be considered for larger defects, for which healing by second intention might be prolonged or expensive. Those reconstructive techniques were advisable when wound contracture or a fragile epithelialised scar might occur (Hunt, 1995).The wound assessment was a complex activity which aimed to collect a large quantity of information to make appropriate decisions for treatment which was the first step in identifying the suitable treatment objectives for the management of wound (Plassmann, 2005). Tracking wound size was an essential part of treatment. The wound's surface area (S) and surface area-to-perimeter (S/P) ratio were useful to document healing (Mavrovitz and Soontupe, 2009).Routine histopathological evaluation of collagen measurement and staining pattern of wound healing processes were performed by using Hematoxylin and Eosin and Masson's trichrome stains.

Ultrasonography and colour-flow Doppler ultrasonography were relatively easy, noninvasive and inexpensive methods to assess the integrity of the direct cutaneous arteries and could potentially be helpful when planning an axial pattern flap for flap survival in clinical cases as performed in the present study. Adipose derived stem cell with a scaffold, acted as a chemo attractant for macrophages, endothelial and epidermal cells and dermal fibroblasts, implicating paracrine signaling in the recruitment of these specific cell types to the wound as reported by Lee $e t$ al., (2011). Adipose-derived stem cells significantly increased the flap viability of random pattern skin flap in the study as also observed by Nanjappa et al., (2014). The aim of the present study was to determine the uptake of skin flap in chronic wounds treated with Adipose Derived Stem Cell in dogs.

\section{Materials and Methods}

The study was carried out on six dogs that were brought to Madras Veterinary College Teaching Hospital, Chennai with large wound that required skin flaps. The omental tissue (Plate 1) was processed at The Centre for Stem Cell Research and Regenerative Medicine, Madras Veterinary College. The omental tissue was washed extensively with equal volumes of PBS (Phosphate Buffered Saline) containing antibiotics (1000 IU/ml of penicillin and $1 \mathrm{~g} / \mathrm{ml}$ of streptomycin) under sterile condition. (Plate 2) The tissues were subjected to dissociation with $0.075 \%$ collagenase for a period of 30 to 45 minutes and the content was sieved using $100 \mu \mathrm{m}$ filter (Plate 3). The enzyme activity was neutralized by washing the cells with DMEMHG (Dulbecco's modified Eagle Medium High Glucose) containing 10\% FBS (Fetal bovine serum). The resultant content was centrifuged at $1200 \mathrm{~g}$ for 5 to 10 minutes to pellet the cells.(Plate 4) The cells were seeded in tissue culture plates at a density of 3000 to 3500 cells per $\mathrm{cm}^{2}$ in DMEM-HG with $10 \%$ FBS containing antibiotics (1000 IU/ml of penicillin and $1 \mathrm{~g} / \mathrm{ml}$ of streptomycin)( Plate 5). The cultures were maintained at $37^{\circ} \mathrm{C}$ under $5 \% \quad \mathrm{CO}_{2}$ tension in growth medium. The cultures were washed with PBS to remove unattached cells and then replaced with fresh media after 24 hours. The cells were subjected to trypsinization when they reached a confluence of $70 \%$, using $0.025 \%$ trypsin and then plated at a density of 5000 cells per $\mathrm{cm}^{2}$. Later, the cultures were passaged repeatedly after achieving a density of 70 to $80 \%$ (Kim et al., 2013). The Endotoxin content was performed by the Limulus amebocyte lysate (LAL) test and the adequacy was $2.5 \mathrm{EU} / \mathrm{ml}$ (Wagers and Wisseman, 2004).The omental tissue was processed at The Centre for Stem Cell Research and Regenerative Medicine, Madras Veterinary College. The omental tissue was washed extensively with equal volumes of 
PBS (Phosphate Buffered Saline) containing antibiotics $(1000 \mathrm{IU} / \mathrm{ml}$ of penicillin and 1 $\mathrm{g} / \mathrm{ml}$ of streptomycin) under sterile conditions. The tissues were subjected to dissociation with $0.075 \%$ collagenase for a period of 30 to 45 minutes and the content was sieved using $100 \mu \mathrm{m}$ filter. The enzyme activity was neutralized by washing the cells with DMEM-HG (Dulbecco's modified Eagle Medium - High Glucose) containing 10\% FBS (Fetal bovine serum). Fu, X. and $\mathrm{Li}, \mathrm{H}$. (2009). The canine adipose cells, thus obtained (Plate 6) not exceeding the second passage was used for topical administration with appropriate substrate on the recipient wound bed.( Plate 7)

After proper granulation, appropriate skin flap technique for the wound was decided based on the wound healing parameters (Ojingwa and Isseroff, 2003). The following skin flaps were performed viz., Single pedicle advancement flap, Flank and elbow rotational flap, Transposition flap and caudal superficial epigastric flap ( plate $8,9,10,11,12$ ).

Subjective evaluation of wound healing based on the physical observations such as colour, odour and presence of exudates for recipient wound bed and skin flap respectively were performed (Table 1). Clinical Photography, Wound Planimetry studies were evaluated. Additionally, biochemical, and histopathological evaluation were done for the recipient wound bed and skin flap. The total protein content from wet granulated tissue samples were performed as per standard protocol.

A subjective analysis of vascularity of the donor site was performed through Colour flow Doppler ultrasonography. After reconstructive surgery, skin flap vascularity and uptake were analysed by the same procedure on $3^{\text {rd }}, 7^{\text {th }}$ and $14^{\text {th }}$ day respectively. The procedure was repeated post operatively to assess the cutaneous arteries on the skin flap on $3^{\text {rd }}, 7^{\text {th }}, 14^{\text {th }}$ day.

\section{Results and Discussion}

The wound planimetry studies of the recipient wound bed are presented in Table 2.The percentage of epithelisation, contraction and wound healing of recipient wound bed treated by Adipose Derived Stem Cell are presented in Table 3.

The percentage of epithelisation, contraction and wound healing on $0,3^{\text {rd }}, 7$ th and $14^{\text {th }}$ day prior to skin flap, revealed a statistically significant increase. There was significant increase in epithelisation, contraction and wound healing on $3^{\text {rd }}, 7^{\text {th }}$ and $14^{\text {th }}$ day respectively. The slight red colour of wound bed on 3rd day might be due to adipose stem cells that promoted wound healing by increasing vessel density, granulation tissue thickness and collagen deposition. In the present study, the colour of skin flap on 3rd day was predominantly pink, portions of the flap passed from red to pink overtime without necrosis. Colour changes in the early stages of circulatory obstruction could have been due to various reasons as opined by Slatter (2003).

Single Pedicle advancement flap were performed in one case with wound on the flank. Transposition flap were performed in one case which had chronic wounds in the left lateral thorax .The Elbow rotational and flank fold flap were performed in one case each respectively. Caudal epigastric flap was performed in one case. Although the skin was considered as a potential "donor" area for wound closure, the closed donor site was more prone to dehiscence in an active pet but proper immobilisation technique and rest prevented the above complications in the study. In view of the fact that $100 \%$ flap survival occurred in single pedicle and transposition flap but caudal epigastric flap 
showed survival of at least as good, if not better, than the other result. Pavletic (2003) Vessel kinking and shortening through rotation and transposition become major obstacles when these types of flaps are rotated more than 90 degrees which was considered as precautionary step when transposition flap was done (Connery and Bellenger, 2002).

The mean \pm S.E. values of total protein of granulation tissue showed a significant increase $(\mathrm{P}<0.05)$ in total protein content in granulation tissue on $3^{\text {rd }}, 7^{\text {th }}$ and $14^{\text {th }}$ day was $4.36 \pm 0.21,4.97 \pm 0.28,5.03 \pm 0.23$. The mean \pm S.E. values for collagen proliferation, epithelisation and angiogenesis was $2.20 \pm$ $0.63,2.30 \pm 0.51,2.35 \pm 0.71$ and $1.72 \pm 0.80$, $1.40 \pm 0.63,2.97 \pm 0.03$ and $2.47 \pm 0.71,1.88$ \pm 0.59 and $1.50 \pm 0.22,23.27 \pm 0.62$, on $3^{\text {rd }}$, $7^{\text {th }}$ and $14^{\text {th }}$ day respectively.

Table.1 Clinical observation of the recipient wound bed and skin flap of Adipose Derived Stem Cell Animals

\begin{tabular}{|c|c|c|c|c|c|c|c|}
\hline \multirow[t]{2}{*}{ Parameters } & \multirow[t]{2}{*}{ Days } & \multicolumn{6}{|c|}{ Adipose derived stem cell treated animals } \\
\hline & & 1 & 2 & 3 & 4 & 5 & 6 \\
\hline \multirow[t]{4}{*}{ Colour of open wound } & Day 0 & Y & B & Y & Y & B & Y \\
\hline & Day 3 & SR & $\mathrm{Y}$ & SR & SR & $\mathrm{Y}$ & SR \\
\hline & Day 7 & $\mathrm{R}$ & SR & $\mathrm{R}$ & $\mathrm{R}$ & $\mathrm{R}$ & $\mathrm{R}$ \\
\hline & Day 14 & $\mathrm{R}$ & $\mathrm{R}$ & $\mathrm{R}$ & $\mathrm{R}$ & $\mathrm{R}$ & $\mathrm{R}$ \\
\hline \multirow[t]{3}{*}{ Colour of skin flap } & Day 3 & $\mathrm{P}$ & $\mathrm{P}$ & B & $\mathrm{P}$ & $\mathrm{R}$ & $\mathrm{P}$ \\
\hline & Day 7 & $\mathrm{P}$ & $\mathrm{P}$ & $\mathrm{R}$ & $\mathrm{P}$ & $\mathrm{P}$ & $\mathrm{P}$ \\
\hline & Day 14 & $\mathrm{P}$ & $\mathrm{P}$ & $\mathrm{P}$ & $\mathrm{P}$ & $\mathrm{P}$ & $\mathrm{P}$ \\
\hline \multirow[t]{4}{*}{ Odour of open wound } & Day 0 & $\mathrm{M}$ & $\mathrm{P}$ & $\mathrm{P}$ & $\mathrm{P}$ & $\mathrm{O}$ & $\mathrm{O}$ \\
\hline & Day 3 & M & M & M & M & $\mathrm{M}$ & M \\
\hline & Day 7 & $\mathrm{~N}$ & M & $\mathrm{N}$ & $\mathrm{N}$ & $\mathrm{M}$ & $\mathrm{N}$ \\
\hline & Day 14 & $\mathrm{~N}$ & $\mathrm{~N}$ & $\mathrm{~N}$ & $\mathrm{~N}$ & $\mathrm{~N}$ & $\mathrm{~N}$ \\
\hline \multirow[t]{3}{*}{ Odour of flap } & Day 3 & $\mathrm{M}$ & M & M & $\mathrm{M}$ & $\mathrm{N}$ & $\mathrm{N}$ \\
\hline & Day 7 & $\mathrm{~N}$ & $\mathrm{~N}$ & $\mathrm{~N}$ & $\mathrm{~N}$ & $\mathrm{~N}$ & $\mathrm{~N}$ \\
\hline & Day 14 & $\mathrm{~N}$ & $\mathrm{~N}$ & $\mathrm{~N}$ & $\mathrm{~N}$ & $\mathrm{~N}$ & $\mathrm{~N}$ \\
\hline \multirow{4}{*}{ Exudate of open wound } & Day 0 & $\mathrm{E}$ & $\mathrm{E}$ & $\mathrm{E}$ & $\mathrm{E}$ & $\mathrm{E}$ & $\mathrm{E}$ \\
\hline & Day 3 & ME & ME & ME & ME & $\mathrm{E}$ & ME \\
\hline & Day 7 & $\mathrm{~N}$ & $\mathrm{~N}$ & $\mathrm{~N}$ & $\mathrm{~N}$ & ME & $\mathrm{N}$ \\
\hline & Day 14 & $\mathrm{~N}$ & $\mathrm{~N}$ & $\mathrm{~N}$ & $\mathrm{~N}$ & $\mathrm{~N}$ & $\mathrm{~N}$ \\
\hline \multirow[t]{3}{*}{ Exudate of the flap } & Day 3 & $\mathrm{Me}$ & $\mathrm{Me}$ & E & $\mathrm{Me}$ & $\mathrm{Me}$ & $\mathrm{Me}$ \\
\hline & Day 7 & $\mathrm{~N}$ & $\mathrm{~N}$ & $\mathrm{E}$ & $\mathrm{Me}$ & $\mathrm{N}$ & $\mathrm{N}$ \\
\hline & Day 14 & $\mathrm{~N}$ & $\mathrm{~N}$ & $\mathrm{~N}$ & $\mathrm{~N}$ & $\mathrm{~N}$ & $\mathrm{~N}$ \\
\hline
\end{tabular}


Table.2 Wound planimetry studies of the recipient wound bed of Adipose derived stem cell animals

\begin{tabular}{|c|c|c|c|c|c|}
\hline \multirow[t]{2}{*}{ Case No. } & \multirow[t]{2}{*}{ Characteristics } & \multicolumn{4}{|c|}{ Wound Healing \% } \\
\hline & & Day 0 & Day 3 & Day 7 & Day 14 \\
\hline \multirow{3}{*}{1} & Epithelisation & 23.54 & 25.68 & 35.99 & 48.26 \\
\hline & Contraction & 24.25 & 26.54 & 36.58 & 53.48 \\
\hline & Wound Healing & 25.35 & 25.34 & 36.25 & 55.36 \\
\hline \multirow{3}{*}{2} & Epithelisation & 21.65 & 23.65 & 34.21 & 52.36 \\
\hline & Contraction & 22.35 & 26.87 & 36.85 & 53.65 \\
\hline & Wound Healing & 26.58 & 25.87 & 35.96 & 54.00 \\
\hline \multirow{3}{*}{3} & Epithelisation & 23.54 & 22.54 & 36.00 & 53.69 \\
\hline & Contraction & 24.12 & 26.65 & 34.56 & 51.26 \\
\hline & Wound Healing & 23.65 & 26.00 & 36.21 & 54.26 \\
\hline \multirow{3}{*}{4} & Epithelisation & 21.25 & 22.65 & 36.25 & 53.26 \\
\hline & Contraction & 22.36 & 23.65 & 34.00 & 50.23 \\
\hline & Wound Healing & 21.25 & 25.32 & 37.23 & 53.26 \\
\hline \multirow{3}{*}{5} & Epithelisation & 24.99 & 25.00 & 35.54 & 51.23 \\
\hline & Contraction & 24.59 & 26.74 & 36.78 & 53.78 \\
\hline & Wound Healing & 25.78 & 26.89 & 37.20 & 53.65 \\
\hline \multirow{3}{*}{6} & Epithelisation & 24.65 & 26.15 & 39.87 & 50.26 \\
\hline & Contraction & 27.65 & 24.83 & 35.99 & 52.69 \\
\hline & Wound Healing & 25.44 & 27.54 & 39.23 & 55.36 \\
\hline
\end{tabular}

Table.3 Percentage of wound epithelisation, wound contraction and wound healing of recipient wound bed of Adipose Derived Stem Cell animal (Mean \pm S.E.)

\begin{tabular}{|c|c|c|c|c|}
\hline \multirow{2}{*}{ ADSC/Days } & \multicolumn{4}{|c|}{ Recipient Wound Bed } \\
\cline { 2 - 5 } & $\mathbf{0}$ Day & $\mathbf{3}^{\text {rd }}$ Day & $\mathbf{7}^{\text {th }}$ Day & $\mathbf{1 4}^{\text {th }}$ Day \\
\hline $\mathbf{6}$ animals & $23.27^{*} \pm 0.62^{\mathrm{a}}$ & $24.28^{*} \pm 0.63^{\mathrm{b}}$ & $36.42^{*} \pm 0.77^{\mathrm{c}}$ & $51.51^{*} \pm 0.83^{\mathrm{d}}$ \\
\hline $\mathbf{6}$ animals & $24.21^{*} \pm 0.78^{\mathrm{a}}$ & $25.68^{*} \pm 0.53^{\mathrm{b}}$ & $35.79^{*} \pm 0.50^{\mathrm{c}}$ & $52.56^{*} \pm 0.60^{\mathrm{d}}$ \\
\hline $\mathbf{6}$ animals & $24.68^{*} \pm 0.40^{\mathrm{a}}$ & $26.16^{*} \pm 0.36^{\mathrm{b}}$ & $37.01 \pm 0.49^{\mathrm{c}}$ & $54.32 \pm 0.36^{\mathrm{d}}$ \\
\hline
\end{tabular}

Means bearing different superscripts in rows and columns vary significantly $(* \mathrm{P}<0.05)$ or $(* * \mathrm{P}<0.01)$ 
Table.4 Colour-flow Doppler ultrasonographic assessment of the donor site and skin flap in adipose derived stem cell treated animals

\begin{tabular}{|l|l|c|c|c|}
\hline Cases & \multicolumn{1}{|c|}{ Donor Site } & \multicolumn{3}{c|}{ Skin Flap( Recipient ) } \\
\cline { 3 - 5 } & & Day 3 & Day7 & Day14 \\
\hline 1. & $1-3 \min$ ( Lateral Neck ) & $3-5 \mathrm{~min}$ & $1-3 \mathrm{~min}$ & $1-3 \mathrm{~min}$ \\
\hline 2. & $3-5 \mathrm{~min}$ ( Frontal ) & $3-5 \mathrm{~min}$ & $1-3 \mathrm{~min}$ & $1-3 \mathrm{~min}$ \\
\hline 3. & $1-3 \mathrm{~min}$ ( Scapula ) & $>5 \mathrm{~min}$ & $3-5 \mathrm{~min}$ & $1-3 \mathrm{~min}$ \\
\hline 4. & $1-3 \min$ (Thorax) & $3-5 \mathrm{~min}$ & $1-3 \mathrm{~min}$ & $1-3 \mathrm{~min}$ \\
\hline 5. & $1-3 \min$ (Flank) & $>5 \mathrm{~min}$ & $3-5 \mathrm{~min}$ & $1-3 \mathrm{~min}$ \\
\hline 6. & $1-3 \mathrm{~min}$ (Abdomen) & $3-5 \mathrm{~min}$ & $1-3 \mathrm{~min}$ & $1-3 \mathrm{~min}$ \\
\hline
\end{tabular}

plate 1 omental tissue

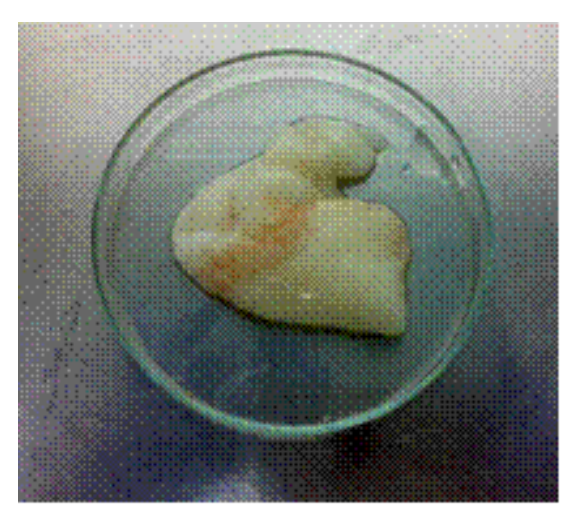

plate 3 Test tube With $0.075 \%$ collagenase
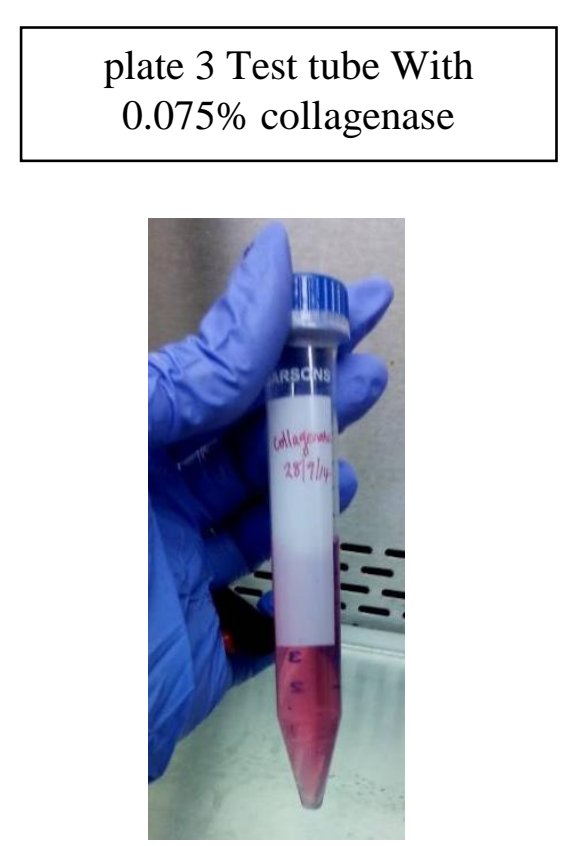

plate 2 PBS Penicillin and

Streptomycin with omental tissue

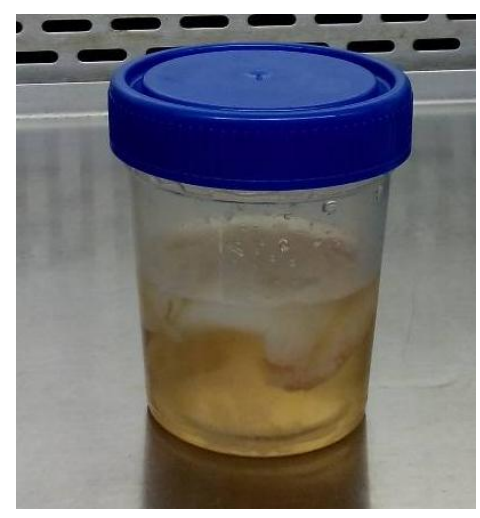

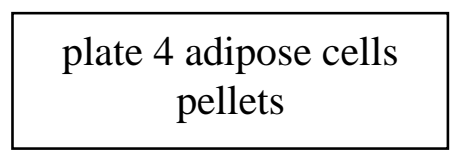

plate 5 Tissue culture plates 3000 to 5000 cells

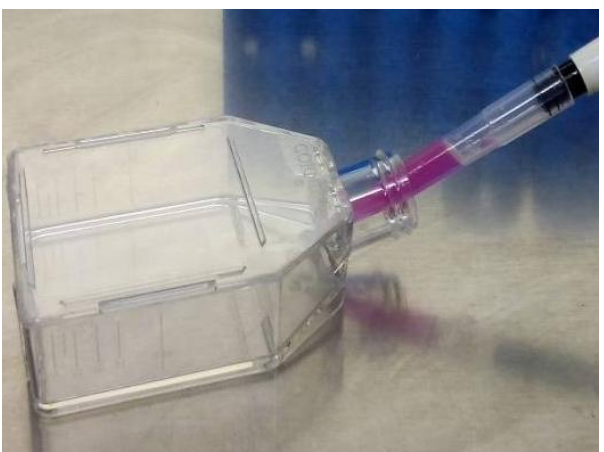



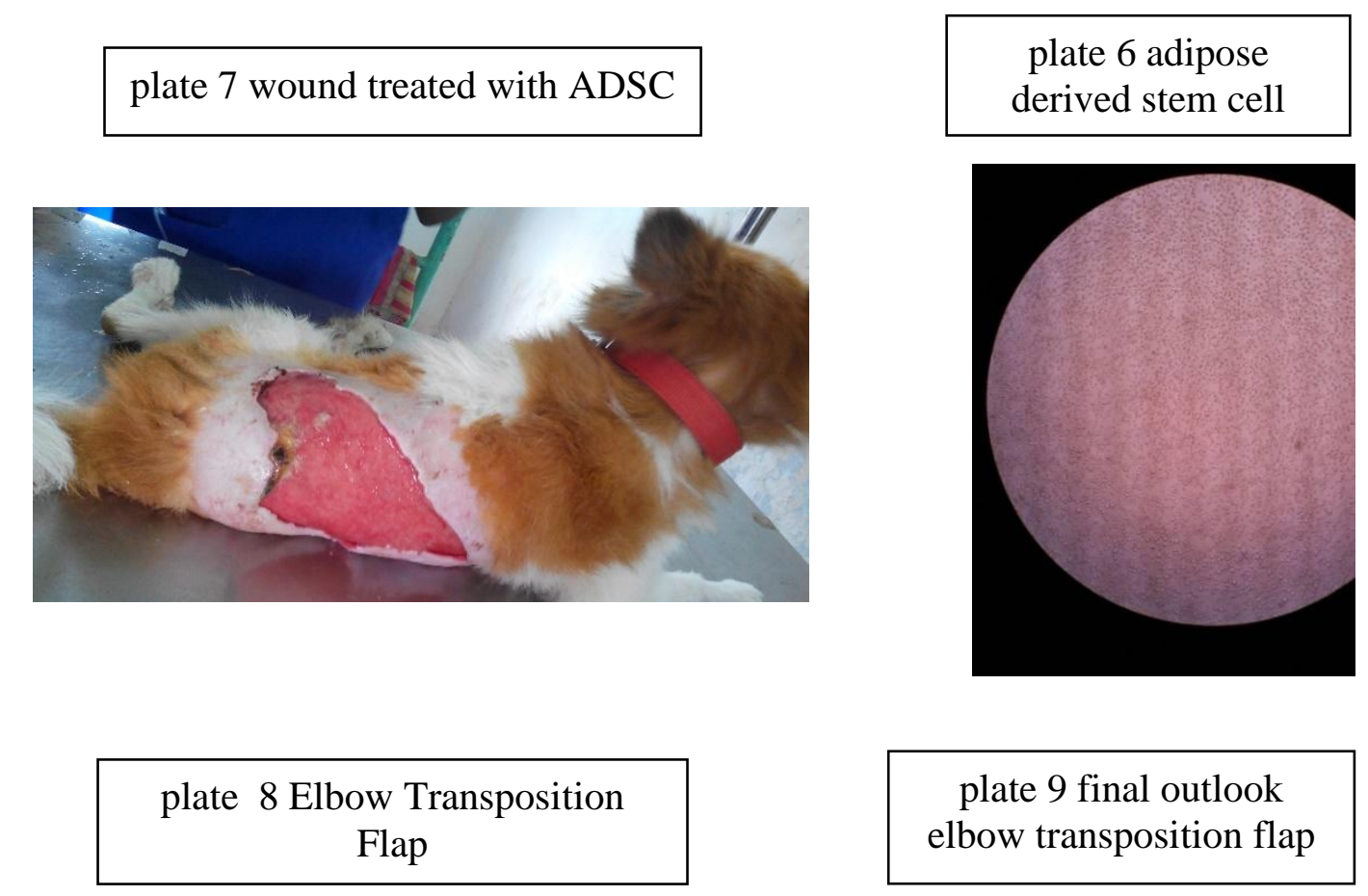

plate 9 final outlook elbow transposition flap
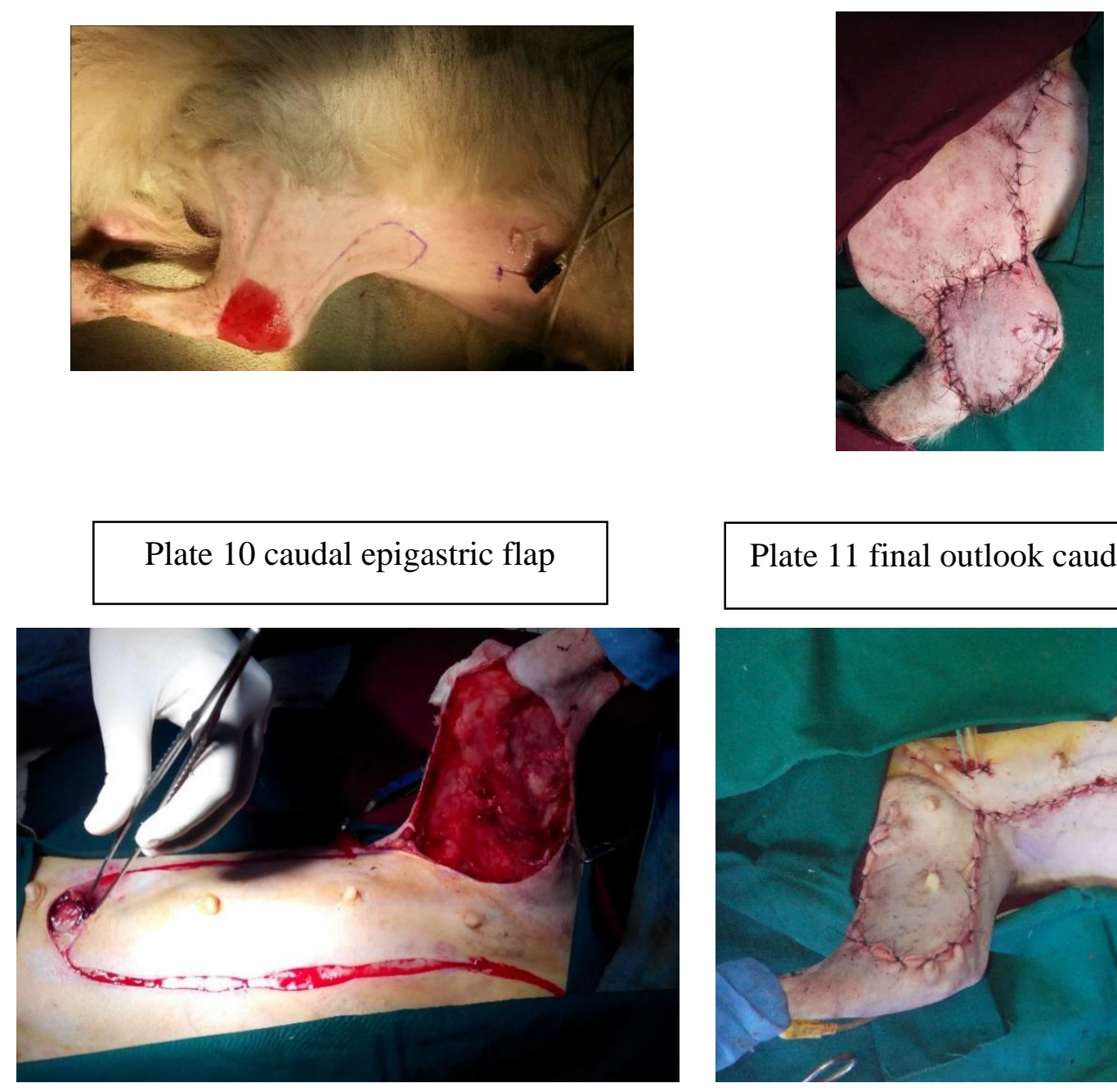

Plate 11 final outlook caudal epigastric flap

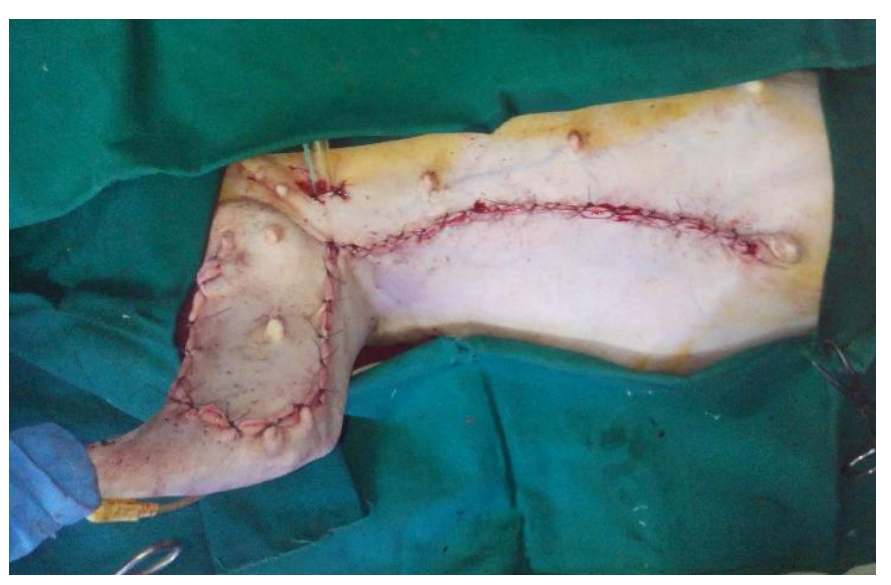




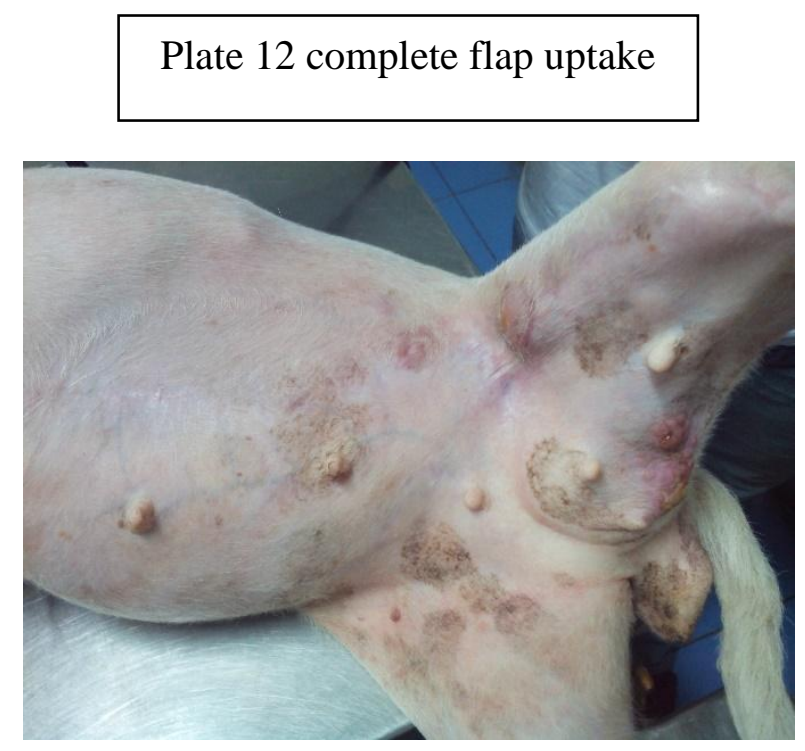

The degree of confidence in locating cutaneous artery was subjectively graded as high, moderate, or low. A high level of confidence was observed for vessel that was located within 1 to 3 minutes and that its identity was not questioned on donor site. A moderate level of confidence was observed for vessel that was located within 3 to 5 minutes on donor site. A low level of confidence (> 5 minutes) was not encountered in the study on the donor sites. (Table 4)( Plate 13,14)

Thus, it was important to assess the integrity of the cutaneous vessels before constructing an axial pattern and a subdermal plexus flap to reconstruct a traumatic wound. Because of relatively small diameter of these vessels and their superficial location, 10 to $12 \mathrm{MHz}$ linear transducer was best for obtaining diagnostic information. A low level of confidence (> 5 minutes) was not encountered in the study on the donor sites. This may be due to the selection of established donor sites and better perfused areas adjacent to the flap designed by subdermal plexus and collateral blood vessels (Reetz et al., 2006)

Adipose derived stem cells promoted fibroblastic proliferation resulting in intensified granulation tissue formation Kilroy et al., (2007). The accumulation of large collagen fibres likely increased the wound strength as opined by Kim et al., (2013) also. Adipose derived stem cells exerted paracrine effects on wound healing such as promoting fibroblast proliferation and exaggerating angiogenesis as opined by Lee et al., (2011).

Angiogenesis and Fibroplasia was higher on the recipient wound bed and skin flap. Adipose derived stem cell with a scaffold, acted as a chemo attractant for macrophages, endothelial and epidermal cells and dermal fibroblasts, implicating paracrine signaling in the recruitment of these specific cell types to the wound as reported by Lee et al., (2011). Adipose-derived stem cells significantly increased the flap viability of random pattern skin flap in the study as also observed by Nanjappa et al., (2014).

\section{Acknowledgement}

The authors acknowledge the Dean, Madras Veterinary College and Director of Clinics, Madras Veterinary College Teaching Hospital for providing necessary support to carryout this project. 


\section{References}

Connery, N.A. and Bellenger, C.R. (2002). Surgical management of haemangiopericytoma involving the biceps femoris muscle in four dogs. Journal of Small Animal Practice. 43, 497-500.

Hunt, G., Geraldine, B., Penelope, L.C., Julius, M., Liptak. and Richard, M. 1995. Skin Fold Advancement Flaps for Closing Large Proximal Limb and trunk defects in dogs and cats. Veterinary surgery. 30:440-448.

Kilroy, G.E., Foster, S.J., Wu, X., Ruiz, J., Sherwood, S., Heifetz, A., Ludlow, J.W. and Gimble, J.M. 2007. Cytokine profile of human adipose-derived stem cells: expression of angiogenic, hematopoietic, and pro-inflammatory factors. J. Cell. Physio. 212: 702-709.

Mayrovitz, H.N. and Soontupe, L.B. 2009. Wound areas by computerized planimetry of digital images: accuracy and reliability. Adv. Skin. Wound. Care. 22 (5): 222-9.

Pavletic, M.M. 2003. Skin and Adnexa. Textbook of small animal surgery Ed D. Slatter, Vol.1, 3rd ed, pp 250259.Saunders.philadelphia.

Reetz, J.A., Seiler, G., Mayhew, P.D. and Holt, D.E. 2006. Ultrasonographic and color flow Doppler ultrasonographic assessment of direct cutaneous arteries used for axial pattern skin flaps in dogs. J Am Vet Med Assoc 228: 1361 - 1366.

Schultz, G., Mozingo, D., Romanelli, M. and Claxton, K. 2005. Wound healing and TIME: new concepts and scientific applications. Wound Repair Regen 13 (4 Suppl): S1-S11

Slatter, D.H. Textbook of Small Animal Surgery.
Philadelphia, PA; [Great Britain]: Saunders, 2003.

$\mathrm{Fu}, \mathrm{X}$. and Li, H. 2009. Mesenchymal stem cells and skin wound repair and regeneration: possibilities and questions. Cell Tissue Res. 335: 317-32.

Kim, J.W., Lee, J.H., Lyoo, S.Y., Jung, S. and Myung, P. 2013. The effects of topical mesenchymal stem cell transplantation in canine experimental cutaneous wounds. Vet Dermatol. 24: 242.

Lee, K.B., Choi, J., Cho, S.B., Chung, J.Y., Moon, E.S., Kim, N.S. and Han, H.J. 2011. Topical embryonic stem cells enhance wound healing in diabetic rats. J. Orthop. Res.29:97-102.

Nanjappa, M.D., Ahmad, A., Amarpal, Gugjoo, M.B. and Pawde, A.M. 2014. Caudal Superficial Epigastric Axial Pattern Flap and Stem Cell Therapy for the Management of Large Wound on Medial Aspect of Thigh in a Dog Advances in Animal and Veterinary Sciences. 2 (3): 188 - 191.

Oedayrajsingh-Varma, M.J., Van, S.M., Knippenberg, M., Helder, M.N., KleinNulend, J., Schouten, T.E., Ritt, M.J. and Van Milligen F.J. 2006. Adipose tissuederived mesenchymal stem cell yield and growth characteristics are affected by the tissue-harvesting procedure. Cytotherapy. 8(2):166-77.

Reetz, J.A., Seiler, G., Mayhew, P.D. and Holt, D.E. 2006. Ultrasonographic and color - $\mathrm{fl}$ ow Doppler ultrasonographic assessment of direct cutaneous arteries used for axial pattern skin fl aps in dogs. $J$ Am Vet Med Assoc228: 1361 - 1366.

Wagers, A.J. and Weissman, I.L. 2004. Plasticity of Adult Stem Cells. Cell. 116: 639-648.

\section{How to cite this article:}

Gokulakrishnan, M., L. Nagarajan and Kannan, T. A. 2020. Preparation of Recipient Wound Bed by Adipose Derived Stem Cell for Skin Flaps in Dogs. Int.J.Curr.Microbiol.App.Sci. 9(03): 162-170. doi: https://doi.org/10.20546/ijcmas.2020.903.020 